\title{
Right here... Right now!!! Illusion of Service Quality at Consortium Bank
}

\author{
${ }^{1}$ Prof. Sumangala Talur and ${ }^{2}$ Prof. Prashanth S
}

Ramu was sitting in his cabin, tired and worried. He was totally confused as to what was happening to his bank account. He, for sure had sensed that something has seriously gone wrong with his loan account with Consortium Bank. For no fault of his, the banker was asking him to pay penalty for non - payment of EMIs regularly. Then he discussed this case with his colleague Uma, who was an Ex-banker.

When Uma heard the entire case, she asked Ramu to demand two documents from the bank- One was the statement of account and other was the instruction given by Ramu to debit his salary account on the "i of every month i.e standing instruction request. These two documents could have very easily explained where things had gone wrong.

Ramu, then met the bank manager and requested for the loan account statement and standing instructions copy. To his surprise, the tone of the bank manager changed! There was a sudden change in the attitude of the manager, from being curt to far more mellow. He even offered tea and tried to explain that the documents were not important and were not required at that point in time. It appeared that the manager could distinctly sense some problem.
The Consortium bank: The Consortium bank is a nationalized bank. Of late, Consortium bank has been modernizing to keep pace with the industry. Though Consortium bank claims to offer all modern facilities, the customer experience with this bank branch has not been pleasant for most customers. Many a time, the ATM attached to the branch remains closed/not functional. Customers are shocked to find that nobody responds to their calls made to customer care! The employees of this bank branch don't seem to be aware of the changes that are happening in the industry. They take customers for granted.

Ramu is a MBA graduate and works as an Assistant professor in an educational institute in Bangalore. Since the college management banks with Consortium bank, all employees are expected to have a savings account with the same bank for crediting their salary. Employees of the college have no choice but to bank with Consortium bank.

Background: It was in Nov 2011, Ramu was getting married and he felt that he needed to take a personal loan for the same. Since he had a salary account with Consortium bank it was easy for him to get the loan sanctioned from them. He decided to borrow two lakh rupees at $14.5 \%$ interest rate and tenure of the loan was 2

Prof. Sumangala Talur
Assistant Professor
Adarsh Institute of management and
Information technology
Bangalore
E-mail : sumangalatalur@yahoo.com


yrs. The EMI was Rs. 6,123/-. Ramu opted for automatic debit (ECS) of EMI from his salary account. He felt that it is very simple and hassle free and hence Ramu was reasonably sure that he would not default on any EMI payments.

After five months, Ramu noticed that EMI is not being deducted from his savings account and he brought this to the notice of the bank. Immediately Rs. 28000/- was debited from his account towards loan repayment. Once again the bank was given fresh instruction to execute the standing instruction for loan repayment. But the bank failed to do so and continued with the same mistake. Unfortunately, Ramu was not aware of it.

Ramu's woes appeared endless. Ramu wished to make a payment of Rs.56000/- towards repayment of loan. He approached the bank and made the request to transfer Rs. 56000/from his savings account to his loan account. After a few months, Ramu got a letter from the bank asking him to pay penalty for nonpayment of EMIs. Another shock awaited him. The bank had transferred Rs. 56000/- to some other loan account instead of Ramu's loan account. The Consortium bank, on enquiry, coolly said that they reversed that erroneous transaction. But Ramu's loan account officially was not showing any repayment entries. Why a customer has to pay penalty for the mistakes committed by the bank?

Dejected by all the mess up in his account, Ramu decided to pre-close his loan account. He requested the bank to provide information on the outstanding amount. On asking, the bank people informed him it is only Rs.46000/-. While Ramu was busy arranging the amount for pre-closure of the account, he got call from bank manager to inform him that it was not the correct figure, but correct outstanding amount was $46000+28000 /-$.Then the manager explained that this was because of another erroneous credit into his loan account. At This point of time Ramu decided to approach to Ombudsman to seek justice.

Ramu contacted Ombudsman and explained his case. People at Ombudsman were very courteous and listened to his complaint very patiently. The officer summoned the branch manager and also the matter to the regional officer of Consortium bank. After the mediation by Ombudsman officer, the regional manager promised to resolve this issue at the earliest. The regional manager has also promised to waive off the additional Rs. 28000/- which Ramu was asked to pay in addition to Rs. $46000 /$ - to pay off his loan completely.

Ramu is now awaiting for the solution which bank is yet to offer. He may get compensation for the financial losses he has incurred, but what about the mental agony he has gone through? What about the time he had to spend visiting the bank and the ombudsman? Can it be quantified?

\section{ANNEXURE:}

A. PROCEDURE TOSANCTION LOAN:

a. Receiving of the application from the bank

b. Duly filling the form

c. Submission of the required documents such as Identity proof, address proof, income proof etc.

d. Verification and application processing done by bank

ECS - It is a mode of electronic funds transfer from one bank account to another bank account using the services of a Clearing House. This can be used both for making payments telephone bills, electricity bills, or charges such as house tax, water tax, etc or for loan installments of financial institutions/banks or regular installments payment. 
e. Sanction the loan and credit to customer loan account.

\section{B. ANOTE ON OMBUDSMAN}

The banking ombudsman in India is a very strong appellate authority which watches the banking sector with hawk's eye. Banking Ombudsman is a higher official appointed by the RBI. The objective of appointing an Ombudsman is to settle customer grievances against deficiency in some banking services. This appointed Ombudsman is either a General Manger or a Chief General Manager of RBI. Banking Ombudsman scheme is applicable throughout India and all banks are covered under this scheme. The banks may be public sector bank, Private Sector Banks, Foreign Banks and Co-operative Banks.

\section{PROCEDURE FOR REDRESSAL OF GRIEVANCE GROUNDS OF COMPLAINT}

1. Any person may file a complaint with the Banking Ombudsman having jurisdiction on any one of the following grounds alleging deficiency in banking including internet banking or other services.

2. A complaint on any one of the following grounds alleging deficiency inbanking service in respect of loans and advances may be filed with the Banking Ombudsman having jurisdiction.

3. The Banking Ombudsman may also deal with such other matter as may be specified by the Reserve Bank from time to time in this behalf.

\section{PROCEDURE FOR FILING COMPLAINT}

1. Any person who has a grievance against a bank on any one or more of the grounds mentioned in Clause 8 of the Scheme may, himself or through his authorized representative (other than an advocate), make a complaint to the Banking Ombudsman within whose jurisdiction the branch or office of the bank complained against is located.

2. Provided that a complaint arising out of the operations of credit cards and other types of services with centralized operations, shal! be filed before the Banking Ombudsman within whose territorial jurisdiction the billing address of the customer is located.

(a) The complaint in writing shall be duly signed by the complainant or his authorized representative.

(b) The complainant shall file along with the complaint, copies of the documents, if any, which he proposes to rely upon and a declaration that the complaint is maintainable under sub-clause (3) of this clause.

(c) A complaint made through electronic means shall also be accepted by the Banking Ombudsman.

(d) The Banking Ombudsman shall also entertain complaints covered by this Scheme received by Central Government or Reserve Bank and forwarded to him for disposal.

(3) No complaint to the Banking Ombudsman shall lie unless:-

(a) the complainant had, before making a complaint to the Banking Ombudsman, made a written representation to the bank and the bank had rejected the 
complaint or the complainant had not received any reply within a period of one month after the bank received his representation or the complainant is not satisfied with the reply given to him by the bank;

(b) The complaint is made not later than one year after the complainant has received the reply of the bank to his representation or, where no reply is received, not later than one year and one month after the date of there presentation to the bank;

(c) The complaint is not in respect of the same cause of action which was settled or dealt with on merits by the Banking Ombudsman in any previous proceedings whether or not received from the same complainant or along with one or more complainants or one or more of the parties concerned with the cause of action;

(d) the complaint does not pertain to the same cause of action, for which any proceedings before any court, tribunal or arbitrator or any other forum is pending or a decree or Award or order has been passed by any such court, tribunal, arbitrator or forum;

(e) The complaint is made before the expiry of the period of limitation prescribed under the Indian Limitation Act, 1963 for such claims.

\section{Reference:}

http://rbidocs.rbi.org.in/rdocs/Content/PDF s/67933.pd 